Journal of Social Sciences 4 (1): 1-6, 2008

ISSN 1549-3652

(C) 2008 Science Publications

\title{
Aggregate Import Demand and Expenditure Components in Ghana
}

\author{
${ }^{1}$ Oteng-Abayie Eric Fosu and ${ }^{2}$ Frimpong Joseph Magnus \\ ${ }^{1}$ Department of Economics, \\ ${ }^{2}$ KNUST School of Business, Department of Finance \& Accounting \\ Kwame Nkrumah University of Science and Technology, Kumasi, Ghana
}

\begin{abstract}
The behaviour of Ghana's imports during the period 1970-2002 was studied using disaggregated expenditure components of total national income. We used newly developed bounds testing approach to cointegration and estimated an error correction model to separate the short- and long-run elements of the import demand relationship. The study revealed inelastic import demand for all the expenditure components and relative price. In the long-run, investment and exports were the major determinant of movements in imports in Ghana. In the short run household and government consumption expenditures was the major determinant of import demand. Import demand was not very sensitive to price changes.
\end{abstract}

Key words: Ghana, import demand, cointegration, relative prices, elasticities

\section{INTRODUCTION}

Ghana is classified as a low income country with real GDP per capita in 2002 of US\$428.6. Ghana has a population of around 20.4 million inhabitants as of 2004 and has about $40 \%$ of the population living under the national poverty line ${ }^{[1]}$. Ghana's macroeconomic performance has been rather sluggish over the last two decades. Economic growth has stagnated around 4.7 per cent per annum. In 2004 the Ghanaian economy grew by 5.5 per cent and a higher growth rate of 5.8 per cent is forecasted for $2005^{[2]}$.

In Ghana, imports as a share of GDP has been rising strongly, particularly over the past three decades. Again over the past 30 years imports have fluctuated considerably, generally in line with changes in real GDP. A significant portion - about 55 per cent - of Ghana's GDP was spent on import payments in 2002. Given the importance of imports for Ghana's economic growth and development and the ensuing implications on the balance of payments, the central aim of this study is to estimate the aggregate import demand for Ghana during the period 1970 to 2002.

The economy has been going through structural changes in recent years. Ghana has not remained a primarily agricultural economy. The share of agriculture in GDP has declined from about $45 \%$ in 1990 to about $36 \%$ in 2004. During the same period, the manufacturing and services sectors increased from $16.8 \%$ and $38.4 \%$ to about $25 \%$ and $39 \%$ respectively.
In 2001, exports and imports of manufactures stood at $16.35 \%$ of merchandise exports and $56.29 \%$ of merchandise imports respectively ${ }^{[1]}$.

Ghana has become more open since trade liberalisation in the early 1980s. In 2002, Ghana exported $\$ 2624.97$ million worth of goods and services but the total imports bill was $\$ 3,379.94$ million $^{[1]}$. The country continues to have a negative trade balance. In 2002, Ghana's external trade balance on goods and services stood at a deficit of $\$ 754.96$ million about $12.3 \%$ of GDP. The indicator for trade openness (Trade as a percent of GDP) in the economy has increased consistently since the liberalisation from $6.3 \%$ in 1982 to a peak of $116 \%$ in 2000 and declined to $97.5 \%$ in 2002. Capital goods, crude oil and energy have constituted the most important items of import. However, Ghana also imports a considerable amount of primary raw materials and other intermediate and consumable goods. Non-durable consumable goods imports have become particularly important on Ghana's imports bill due to the declining capacity in domestic production and changing preferences due to globalisation. Although Ghana has embarked on massive export promotion campaign with the promulgation of an Export Free Zone Act, it has not succeeded in increasing export over imports. The import penetration ratio (import as a per cent of GDP) has increased from a minimum of $2.98 \%$ in 1982 to the highest of $67.24 \%$ in 2000 and declined to $54.87 \%$ in 2002.

Corresponding Author: Joseph Magnus Frimpong, KNUST School of Business, Kwame Nkrumah University of Science and Technology, Ghana 
The above analysis shows that external trade is a key determinant of economic growth and development in Ghana. For policy purposes, it is pertinent to know the determinants of aggregate import demand in Ghana. The study, to the best of our knowledge, is the first to use the recent disaggregated import demand formulation approach to study the behaviour of aggregate import demand in Ghana. Following recent studies by ${ }^{[3,4,5]}$, we use the disaggregated components of domestic income (i.e. final demand expenditure components) together with the standard relative price variable to specify the aggregate import demand model for Ghana.

The use of the disaggregated components of total domestic income to estimate aggregate import demand is a relatively recent research approach ${ }^{[3,4,5]}$ different from the traditional approach which uses only domestic income and the relative prices. Two advantages accrue from using the disaggregated import demand model over the traditional aggregate import demand model. The later implicitly assumes that the import contents of all components (consumption, investment and exports) in the final expenditure demand are identical. If this assumption does not hold, the use of a single demand variable will lead to aggregation bias ${ }^{[6]}$. By disaggregating the final demand, the disaggregate model not only can avoid the problem of aggregation bias, but also can be used to estimate the separate effects of each component on import demand. Moreover, by avoiding aggregation problems, the disaggregate model has better forecasting powers than the traditional import demand models ${ }^{[5]}$.

\section{EMPIRICAL LITERATURE}

There is an overplus of studies that examine the causal factors of aggregate import demand models. From the empirical literature we surveyed, no study was found that specifically estimates the determinants of aggregate import demand in Ghana. It is therefore only logical for us to survey the literature that is directly relevant to the theme chosen for this study. At this point, we focus on reviewing only those studies that have used the disaggregate approach.

Abbott and Seddighi ${ }^{[7]}$ used the cointegration approach of ${ }^{[8]}$ and the error correction models of ${ }^{[9]}$ to estimate an import demand model for the UK. From their results consumption expenditure had the largest impact on import demand (1.3) followed by investment expenditure (0.3) and export expenditure (0.1). The relative price variable (the ratio of import price to domestic price) had a coefficient of 20.1.
Mohammed and Tang ${ }^{[10]}$ also used the Johansen and Juselius ${ }^{[8]}$ cointegration technique and estimated the determinants of aggregate import demand for Malaysia, over the period 1970-1998. The results indicated that while all expenditure components had an inelastic effect on import demand in the long run, investment expenditure had the highest correlation (0.78) with imports followed by final consumption expenditure (0.72). Expenditure on exports was found to have the smallest correlation with imports $(0.385)$. They also found a negative (-0.69) and inelastic relationship between relative prices and import demand. All results were found to be statistically significant at the 1 per cent level.

Mohammad et al. ${ }^{[1]}$ examine the long-run relationship between imports and expenditure components of five ASEAN countries (Malaysia, Indonesia, the Philippines, Singapore and Thailand) through Johansen multivariate cointegration analysis $^{[12,13]}$. Annual data for the period 1968-1998 are used for the countries (except Singapore, with a shorter period 1974-1998). The disaggregate model, in which the final demand expenditure is split up into three major components, is used. The results reveal that import demand is cointegrated with its determinants for all five countries.

Min et al. ${ }^{[14]}$ estimated South Korea's import demand using the Johansen and Juselius ${ }^{[8]}$ approach over the 1963-1998 period. They found evidence of long run elastic (1.04) impact of final consumption expenditure on import demand and inelastic (0.49) impact of export expenditure on import demand. Both results were statistically significant at the 1 per cent level. However on the impact of investment expenditure, while they found it to be negatively related with import demand, it was statistically insignificant. On the impact of prices, they found relative prices negatively impacting import demand at the 1 per cent level of significance.

Tang $^{[3]}$ estimated China's import demand using the bounds testing approach to cointegration. In the long run, he found expenditure on exports having the biggest correlation with imports $(0.51)$, followed by investment expenditure $(0.40)$ and final consumption expenditure (0.17). The relative price variable appeared with a coefficient of 20.6, implying that an increase in relative prices induces a 0.6 per cent fall in the demand for imports.

$\mathrm{Ho}^{[4]}$ has also estimated the import demand function of Macao by testing two popular models: (i) aggregate and (ii) disaggregate import demand model with the components of aggregate expenditure using quarterly data over the 1970 to 1986 period. Using JJ- 
Maximum likelihood cointegration and error correction technique, he found significant partial elasticities of import demand with respect to investment $(0.1396)$, exports (1.4810) and relative prices (-0.3041) with their expected signs implied by the economic theory in the disaggregated model.

Narayan $^{[5]}$ recently applied the bounds testing approach to cointegration to estimate the long-run disaggregated import demand model for Fiji using relative prices, total consumption, investment expenditure and export expenditure variables over the period 1970 to 2000 . Their results indicated a long run cointegration relationship among the variables when import demand is the dependent variable; and import demand to be inelastic and statistically significant at the 1 per cent level with respect to all the explanatory variables in both the long-run and the short-run. The results revealed long run elasticities of 0.69 for both export expenditure and total consumption expenditure respectively, followed by relative prices $(0.38)$ and investment expenditure (0.17).

\section{THE IMPORT DEMAND MODEL}

The standard import demand model with income and relative price as the explanatory variables has been the work horse in the literature in both developed and developing countries. Goldstein and Khan ${ }^{[15]}$ presented two trade models: the imperfect substitutes model and the perfect substitutes model. Whilst the perfect substitutes is mainly for the trade of homogeneous goods, the imperfect substitutes is the one mostly used in studying imports of manufactured goods and aggregate imports. Surveys of research on imperfect substitutes modelling include ${ }^{[15,16,17,18,19]}$ among others.

The basic import demand model within the imperfect substitutes framework is expressed in terms of real domestic income $Y_{t}$ and relative prices $R_{t}=$ $\left(\mathrm{p}^{\mathrm{m}} / \mathrm{p}^{\mathrm{d}}\right)_{\mathrm{t}}$ as:

$$
M_{t}=\alpha_{0}+\alpha_{1} Y_{t}+\alpha_{2} R P_{t}
$$

In this study, we follow the formulation used recently by ${ }^{[3,4,5]}$. They specify a simple model where real income $Y_{t}$ is defined as the aggregate demand expenditure is disaggregated into its components of final consumption expenditure $\left(\mathrm{C}_{\mathrm{t}}\right)$, final investment expenditure $\left(\mathrm{I}_{\mathrm{t}}\right)$ and final exports expenditure $\left(\mathrm{X}_{\mathrm{t}}\right)$. We specify the computable disaggregate import demand model as follows:

$$
\begin{aligned}
& \ln \mathrm{M}_{\mathrm{t}}=\alpha_{0}+\beta_{1} \ln \mathrm{C}_{\mathrm{t}}+\beta_{2} \ln \mathrm{I}_{\mathrm{t}}+\beta_{3} \ln \mathrm{X}_{\mathrm{t}}+\gamma \ln \mathrm{RP}_{\mathrm{t}} \\
& +\alpha_{1} \mathrm{D}_{\mathrm{t}}+\varepsilon_{\mathrm{t}}
\end{aligned}
$$

where $M_{t}$ is the real imports of goods and service, $C_{t}$ is the final consumption expenditure (i.e. the sum of household and government final expenditures); $I_{t}$ the expenditure on investment goods (i.e. gross capital formation including change in inventory); and $X_{t}$ is the expenditure on total exports of goods and services. All are in billions of cedis. $\mathrm{RP}_{\mathrm{t}}$ is the relative prices (the ratio of import price index to domestic price index), D is a dummy variable for trade liberalisation policy and $\varepsilon_{t}$ is the i.i.d error term, at period t. Following ${ }^{[19]}$, the index of trading partners' export price indices is used to proxy import price index for Ghana, since data for import price index is not available. From the law of demand, an increase in import prices reduces demand for imports as imported goods become relatively more expensive while demand for imported goods increase as domestic prices increase $(\gamma<0)$. Therefore, it is expected that import price relative to domestic price will be negatively related to real import. We expect the coefficients associated with the expenditure components $\left(C_{t}, I_{t}\right.$ and $\left.X_{t}\right)$ to be positive (i.e. $\beta_{1}>0$, $\beta_{2}>0, \beta_{3}>0$ ). Equation (2) represents only the long-run equilibrium state of import demand.

However, for policy reasons, the short run adjustment of imports to changes in its determinants is imperative. They fail to recognise the dynamic adjustment behaviour of import demand. A basic assumption is that importers are always on their demand schedules such that demand for imports always equals the actual level of imports. Nevertheless, it is generally recognized that imports do not immediately adjust to their long run equilibrium level following a change in any of their determinants ${ }^{[20]}$. Factors such as the costs of adjustment, inertia, delivery lags, etc., cause the slow adjustment by economic agents to the changes in the determinants of import demand.

\section{MATERIALS AND METHODS}

All equations are estimated using annual time series data for the period 1970 to 2002 . The data series used were taken from the International Monetary Fund's International Financial Statistics, 2004, World Bank's World Development Indicators, 2004 and the Bank of Ghana Statistical Bulletin. All series were transformed into their natural logs to manage the high magnitudes of the figures.

This study utilises the autoregressive distributed lag (ARDL) bounds testing procedure developed by ${ }^{[21]}$ to examine the cointegration relationship between import demand and its determinants. The choice of this test is based on the following considerations. Firstly, unlike most of the conventional multivariate 
cointegration procedures, which are valid for large sample size, the bound test is suitable for a small sample size study ${ }^{[21]}$. Given that our sample size is limited with a total of 33 observations only, this approach will be appropriate. Secondly, the bounds test does not impose a restrictive assumption that all the variables under study must be integrated of the same order. The F-test has a non-standard distribution and depends upon: whether variables included in the ARDL model are I (0) or I (1); the number of regressors in the system; and whether the ARDL model contains an intercept and/or a trend.

According to ${ }^{[21]}$, to apply the bounds test procedure, a conditional VECM of interest can be specified to test the cointegration relationship between import demand, relative price and the expenditure component variables.

$$
\begin{aligned}
& \Delta \ln \mathrm{M}_{\mathrm{t}}=\alpha_{0}+\delta_{1} \ln \mathrm{M}_{\mathrm{t}-1}+\delta_{2} \ln \mathrm{C}_{\mathrm{t}-\mathrm{l}}+\delta_{3} \ln \mathrm{I}_{\mathrm{t}-\mathrm{l}}+\delta_{4} \ln \mathrm{X}_{\mathrm{t}-1} \\
& +\delta_{5} \mathrm{RP}_{\mathrm{t}-1}+\sum_{\mathrm{i}=0}^{\mathrm{p}} \phi_{\mathrm{i}} \ln \mathrm{M}_{\mathrm{t}-\mathrm{i}}+\sum_{\mathrm{j}=0}^{\mathrm{q}} \varpi_{\mathrm{j}} \mathrm{C}_{\mathrm{t}-\mathrm{j}}+\sum_{\mathrm{l}=0}^{\mathrm{q}} \varphi_{1} \Delta \ln \mathrm{I}_{\mathrm{t}-1} \\
& +\sum_{\mathrm{m}=0}^{\mathrm{q}} \gamma_{\mathrm{m}} \Delta \ln \mathrm{X}_{\mathrm{t}-\mathrm{m}}+\sum_{\mathrm{n}=1}^{\mathrm{q}} \xi_{\mathrm{n}} \Delta \ln \mathrm{RP}_{\mathrm{t}-\mathrm{n}}+\psi \mathrm{D}_{\mathrm{t}}+\varepsilon_{\mathrm{t}}
\end{aligned}
$$

where, all variables are as previously defined. For more detail discussions on the bounds test see ${ }^{[21]}$.

There are three steps in testing the cointegration relationship between import demand and its explanatory variables. First, we estimate equation (3) by ordinary least square (OLS) technique. The presence of cointegration can be traced by conducting an F-test for the joint significance of the coefficients of the lagged levels of the variables. That is, the null hypothesis $\mathrm{H}_{0}: \delta_{1}=\delta_{2}=\delta_{3}=\delta_{4}=\delta_{5}=0$ against the alternative $\mathrm{H}_{\mathrm{A}}: \delta_{1}$ or $\delta_{2}$ or $\delta_{3}$ or $\delta_{4}$ or $\delta_{5} \neq 0$. If the computed F-statistic is less than lower bound critical value, then we do not reject the null hypothesis of no cointegration. Conversely, if the computed F-statistic is greater than upper bound critical value, then we reject the null hypothesis and conclude that there exists steady state equilibrium between the variables under study. However, if the computed value falls within lower and upper bound critical values, then the result is inconclusive. The approximate critical values for the Ftest are obtained from ${ }^{[22]}$. Critical values for the $\mathrm{I}(0)$ series are referred to as the Upper bound critical values, while the critical values for the I(1) series are referred to as the lower bound critical values.

Second, following ${ }^{[21]}$, assuming a unique long-run relationship exist among variables of interest, we specify a conditional ARDL $\left(\mathrm{p}_{1}, \mathrm{q}_{1}, \mathrm{q}_{2}, \mathrm{q}_{3}, \mathrm{q}_{4}\right)$ long-run model for $\mathrm{m}_{\mathrm{t}}$ based on equation (2) as:

$$
\begin{aligned}
& \ln \mathrm{M}_{\mathrm{t}}=\mathrm{c}_{0}+\sum_{\mathrm{i}=1}^{\mathrm{p}} \delta_{1} \ln \mathrm{M}_{\mathrm{t}-\mathrm{i}}+\sum_{\mathrm{i}=0}^{\mathrm{q}_{1}} \delta_{2} \ln \mathrm{C}_{\mathrm{t}-\mathrm{i}}+\sum_{\mathrm{i}=0}^{\mathrm{q}_{2}} \delta_{3} \ln \mathrm{I}_{\mathrm{t}-\mathrm{i}} \\
& +\sum_{\mathrm{i}=0}^{\mathrm{q}_{3}} \delta_{4} \ln \mathrm{X}_{\mathrm{t}-\mathrm{i}}+\sum_{\mathrm{i}=0}^{\mathrm{q}_{4}} \delta_{5} \ln \mathrm{RP}_{\mathrm{t}-\mathrm{i}}+\psi \mathrm{D}_{\mathrm{t}}+\varepsilon_{\mathrm{t}}
\end{aligned}
$$

where, all variables are as previously defined. The lags length in the ARDL model is selected based on Schwarz Bayesian Criterion (SBC) and Akaike Information Criterion. For our annual data ${ }^{[23]}$, suggest a maximum of 2 lags.

In the final step, we obtain the short-run dynamic elasticities by estimating an error correction model associated with the long-run estimates. This is specified as follows:

$$
\begin{aligned}
& \Delta \ln \mathrm{M}_{\mathrm{t}}=\mu+\sum_{\mathrm{i}=1}^{\mathrm{p}} \phi_{\mathrm{i}} \Delta \ln \mathrm{M}_{\mathrm{t}-\mathrm{i}}+\sum_{\mathrm{j}=1}^{\mathrm{q}} \varpi_{\mathrm{j}} \Delta \ln \mathrm{C}_{\mathrm{t}-\mathrm{j}} \\
& +\sum_{\mathrm{l}=1}^{\mathrm{q}} \varphi_{\mathrm{l}} \Delta \ln \mathrm{I}_{\mathrm{t}-1}+\sum_{\mathrm{m}=1}^{\mathrm{q}} \gamma_{\mathrm{m}} \Delta \mathrm{X}_{\mathrm{t}-\mathrm{m}}+\sum_{\mathrm{p}=1}^{\mathrm{q}} \eta_{\mathrm{p}} \Delta \ln \mathrm{RP}_{\mathrm{t}-\mathrm{p}} \\
& +\vartheta \mathrm{ecm}_{\mathrm{t}-1}+\varepsilon_{\mathrm{t}}
\end{aligned}
$$

here $\phi, \varpi, \varphi, \gamma, \eta$ are the short-run dynamic elasticities of the model's convergence to long-run equilibrium and $\vartheta$ is the speed of adjustment. $\Delta$ represents first difference operator and $\mathrm{ecm}_{\mathrm{t}-1}$ is the one period lagged error correction term estimated from equation (2). The coefficient measures the speed of adjustment to obtain equilibrium in the event of shocks to the system.

\section{RESULTS AND DISCUSSION}

Applying the steps enumerated above as $\mathrm{in}^{[24]}$, we first estimated an OLS regression for the first differences part of equation (3) and then test for the joint significance of the parameters of the lagged level variables when added to the first regression. The computed F-statistics from the Wald tests for restrictions imposed on the parameters are reported in Table 1. According the computed F statistics, we can reject the null hypothesis of no cointegration at 1 percent significance level for import demand. The computed F-statistic $\mathrm{F}_{\mathrm{M}}(\mathrm{M} / \mathrm{C}, \mathrm{I}, \mathrm{X}, \mathrm{RP}$. $)=16.1395$ is higher than the upper bound critical value of 5.763 at the 1 per cent significance level. This indicates that the alternative hypothesis of the existence of a unique cointegration relationship between imports demand and its determinants can be accepted for Ghana in this case. 
Table 1: ARDL bounds test for cointegration analysis for equation 3 Critical values (F statistic) for the bounds test: Restricted intercept and no trend ${ }^{\mathrm{a}}$

\begin{tabular}{|c|c|c|c|c|c|c|}
\hline \multirow{2}{*}{4} & \multicolumn{2}{|c|}{$1 \%$ level } & \multicolumn{2}{|c|}{$5 \%$ level } & \multicolumn{2}{|c|}{$10 \%$ level } \\
\hline & $\mathrm{I}(0)$ & $\mathrm{I}(1)$ & $\mathrm{I}(\mathrm{C}$ & $\mathrm{I}(1)$ & $\mathrm{I}(0)$ & $\mathrm{I}(1)$ \\
\hline 4 & 4.223 & 5.763 & 3.002 & 4.150 & 2.493 & 3.497 \\
\hline & $\mathrm{I} / \mathrm{C}, \mathrm{I}, \mathrm{X}$ & & & \multicolumn{3}{|l|}{ Com } \\
\hline
\end{tabular}

${ }^{a}$ Notes: Critical values are extracted from Narayan (2004), pp: 26-28, appendixes 1-3. Critical values for the bounds test: Case II. $k$ is the number of regressors. The asterisks indicate the following levels of significance: $* 5 \%$ and $* * 1 \%$

Table 2: Estimated long run elasticities of import demand using the ARDL approach

ARDL $(1,1,0,0,1)$ selected based on Schwarz Bayesian Criterion. Dependent variable is $\ln \mathrm{M}_{\mathrm{t}}$. 32 observations used for estimation from 1971 to 2002

\begin{tabular}{llll}
\hline Regressor & Coefficient & Standard error & T-ratio [prob] \\
\hline Constant & 0.0917 & 0.9205 & $0.0996[0.922]$ \\
$\operatorname{lnC}_{\mathrm{t}}$ & 0.0831 & 0.4489 & $0.1852[0.855]$ \\
$\operatorname{lnI}_{\mathrm{t}}$ & 0.6332 & 0.1838 & $3.4449[0.002]$ \\
$\ln \mathrm{X}_{\mathrm{t}}$ & 0.6377 & 0.1208 & $5.2794[0.000]$ \\
$\operatorname{lnRP}_{\mathrm{t}}$ & -0.0165 & 0.0442 & $-0.3721[0.713]$ \\
$\mathrm{D}_{\mathrm{t}}$ & -0.0863 & 0.1864 & $-0.4630[0.648]$ \\
\hline
\end{tabular}

In other words, we have proved that import demand, final consumption expenditure, investment expenditure, exports expenditure and relative prices are bound together in the long-run (cointegrated) when import demand is made the dependent variable.

Having established that import demand is cointegrated (has long run relationship) with its determinants, we proceed to estimate equation (4) for the long run elasticities. The selected maximum lag length that minimised the Schwarz Bayesian Criterion (SBC) was 1.

The results for the long run elasticities are reported in Table 2. All the estimated variables have their expected signs. However, consumption expenditure and the relative price variables are insignificant. The elasticity estimates indicates that in the long run, aggregate import demand in Ghana is mostly influenced by both investment and export expenditures with elasticities of 0.63 and 0.64 respectively. Aggregate imports will change by $0.63 \%$ and $0.64 \%$ respectively in response to a $1 \%$ change in investment and export expenditures.

The magnitude of the relative price elasticity suggests that Ghanaians are less responsive to increases in the import price levels. A $1 \%$ change in import prices will only change aggregate imports by $-0.02 \%$, all things being equal. The various measures of impact of the expenditure component on aggregate import demand are therefore very pertinent. The dummy variable for trade liberalisation carries the unexpected
Table 3: Error correction representation for the ARDL import demand ARDL $(1,1,0,0,1)$ selected based on Schwarz Bayesian Criterion. Dependent variable is $\operatorname{lnM}_{\mathrm{t}} .32$ observations used for estimation from 1971 to 2002

\begin{tabular}{|c|c|c|c|}
\hline Regressor & Coefficient & Standard error & T-ratio [prob] \\
\hline Constant & 0.06575 & 0.65900 & $0.0998[0.921]$ \\
\hline$\Delta \operatorname{lnC}_{t}$ & 0.83830 & 0.33596 & $2.4952[0.020]$ \\
\hline$\Delta \ln I_{t}$ & 0.45425 & 0.13053 & $3.4799[0.002]$ \\
\hline$\Delta \ln X_{t}$ & 0.45745 & 0.11878 & $3.8513[0.001]$ \\
\hline$\Delta \operatorname{lnR} P_{t}$ & -0.28471 & 0.13686 & $-2.0803[0.048]$ \\
\hline $\mathrm{D}_{\mathrm{t}}$ & -0.06192 & 0.14094 & $-0.43929[0.664]$ \\
\hline $\mathrm{ecm}_{\mathrm{t}-1}$ & -0.71735 & 0.15061 & $-4.7629[0.000]$ \\
\hline \multicolumn{4}{|l|}{ Diagnostics } \\
\hline $\mathrm{R}^{2}$ & 0.72095 & - & $1.1183[0.572]$ \\
\hline Adj. $R^{2}$ & 0.6239 & $\chi_{\text {Re set }}^{2}$ & $0.1282[0.720]$ \\
\hline F-stat. F $(6,25)$ & $9.904[0.000]$ & $\chi_{\text {Auto }}^{2}$ & $2.3564[0.125]$ \\
\hline S.ER & 0.1117 & $\chi_{\text {White }}^{2}$ & $0.5689[0.451]$ \\
\hline AIC & 21.0236 & SBC & 14.4278 \\
\hline
\end{tabular}

sign and is insignificant and does not affect the results when it was removed. All elasticities are inelastic.

Table 3 reports the results of the short run errorcorrection model (equation 5). All the short-run elasticities have their expected signs and are also statistically significant at the 5 per cent level. The short run results are however a bit different from the long run results. In the short run, consumption expenditure has the highest influence on aggregate import demand, followed by exports and investment expenditures respectively. From the results, a $1 \%$ change in final consumption expenditures will lead to a $0.84 \%$ change in aggregate import bills. A $1 \%$ change in investment and exports expenditures will also lead to a $0.45 \%$ change in aggregate import demand.

The relative price variable once again has the least influence on aggregate import demand as in the longrun. Imports will only change by $-0.28 \%$ when import prices change by $1 \%$. All elasticities are inelastic in the short run too.

Finally, the error correction term, $\mathrm{ecm}_{\mathrm{t}-1}$, which represents the speed of adjustment is significant and carries the correct sign. Therefore the long run equilibrium is achievable. The coefficient -0.72 suggests that in Ghana adjustment from the short run to long run equilibrium is very fast.

A set of diagnostic tests conducted on the short run model revealed no problem with respect to model functional formulation (RESET), normality (JacqueBera), serial correlation and heteroskedasticity in the error term. Also we test for stability of the coefficient estimates using cumulative sum (CUSSUM) and cumulative sum of squares (CUSSUMQ) test. The regression model is found stable within the $5 \%$ bounds level of significance. 


\section{CONCLUSION AND POLICY IMPLICATIONS}

In this study we have used the ARDL bounds testing approach to cointegration to examine the relationship between expenditure components, relative price and aggregate import demand in Ghana. We found a long-run relationships relation among the variables and used it to estimate both long and short run disaggregated import demand model for Ghana.

The study finds that an inelastic and positive relationship exist between the three expenditure components and aggregate import demand. Relative price is also inelastic but negatively impact aggregate demand. The short run results fits the current situation in Ghana and for that matter many African countries as these countries are clearly highly dependent on imports especially for consumption and investment goods to make up for short falls in local production.

For policy implication, this suggests that Ghana will have to improve its price competitiveness in external trade to be able reduce its trade deficits and increase foreign exchange reserves levels. Price competitiveness is also important for the growth and development of local industries and survival of export enclaves.

Finally, the results are also consistent with theory and support the findings of other recent studies such $a^{[5]}$ Narayan and Narayan (2005). It adds to knowledge by providing new estimates for import demand elasticities in Ghana.

\section{REFERENCES}

1. World Bank, 2004. World Development Indicators, Washington D.C.

2. Bank of Ghana, Bank of Ghana Statistical Bulletin, various issues.

3. Tang, T.C., 2003. An empirical analysis of Chinas aggregate import demand function, China Econ. Rev., 12 (2): 142-163.

4. Ho, W.S., 2004. Estimating Macao's import demand functions, monetary authority of Macao.

5. Narayan, P.K. and S. Narayan, 2005. An empirical analysis of Fijis Import Demand Function, J. Economic. Studies, 32 (2): 158-168. Emerald Group Publishing Limited

6. Giovannetti, G., 1989. Aggregate imports and expenditure components in Italy: An econometric analysis, Applied Econ., 21: 957-971.

7. Abbott, A.J. and H.R. Seddighi, 1996. Aggregate imports and expenditure components in the UK: an Empirical Analysis, Applied Economics, 28: 11191125 .

8. Johansen and Juselius, 1990. Maximum likelihood estimation and inference on cointegration with applications the demand for money, Oxford Bulletin of Economics and Statistics, 52 (2): 169-210.
9. Engle, R. and C. Granger, 1987. Cointegration and error correction: representation, estimation and testing, Econometrica, 55: 251-276

10. Mohammed, H.A. and T.C. Tang, 2000. Aggregate imports and expenditure components in Malaysia: a cointegration and error correction analysis, ASEAN Econ. Bull., 17: 257-269.

11. Mohammed, H.A., T.C. Tang and J. Othman, 2001. Aggregate import demand and expenditure components in five ASEAN Countries: An Empirical Study, J. Ekonomi Malaysia, 35: 37-60.

12. Johansen, 1988. Statistical Analysis of Cointegrating Vectors, J. Econo. Dynamic and Control, 12: 231-254.

13. Johansen, et al., 1991. Estimation and hypothesis testing of cointegration vector autoregressive models, Econometrica, 59: 1551-1580.

14. Min, B.S., H.A. Mohammed and T.C. Tang, 2002. An analysis of South Koreas import demand, J. Asia Pacific Affairs, 4: 1-17.

15. Goldstein, M. and M. Khan, 1985. Income and Price Effects in Foreign Trade. In Handbook of International Economics, Vol. 2 (Jones, R. and P. Kenen, Eds.). Amsterdam and New York, North-Holland, Elsevier, 1041-1105.

16. Senhadji, A., 1998. Time-series estimation of structural import demand equations: a crosscountry analysis, IMF Staff Papers, 45 (2): 236-268.

17. Tambi, N.E., 1998. Trade liberalization effects on commodity imports in Cameroon, J. Econ. Stud., 25 (3): 193-202.

18. Sinha, D., 1997. Determinants of import demand in Thailand, Int. Econ. J. 11: 73-83.

19. Agbola, F.W. and M.Y. Damoense, 2005., Timeseries estimation of import demand functions for pulses in India. J. Econ. Studies, 32 (2): 146-157. Emerald Group Publishing Limited.

20. Hasan, Y., J. Mohammad and M.I.T. El-Sakka, 1999. Demand for Imports in the GCC countries 9901, Economic Research Forum.

21. Pesaran, M.H., Shin, Yong Cheol and R. Smith, 2001. Bound Testing Approaches to the Analysis of Level Relationships. J. Applied Econometrics, 16: 289-326.

22. Narayan, P.K., 2004. Reformulating critical values for the bounds F-statictics approach to cointegration: an application to the tourism demand model for Fiji, Department of Economics Discussion Papers N0.02/04, Monash University, Melbourne.

23. Pesaran, M.H., Y. Shin and R.J. Smith, 1999. Bounds Testing Approaches to the Analysis of Long-run Relationships, Cambridge Working Papers in Economics 9907, Faculty of Economics (formerly DAE), University of Cambridge. 